\title{
STRUKTUR TAHANAN JENIS SISTEM PANAS BUMI DOLOK MARAWA-SUMATERA UTARA BERDASARKAN DATA AUDIO MAGNETOTELLURIK
}

\section{RESISTIVITY STRUCTURE OF DOLOK MARAWA GEOTHERMAL SYSTEM, NORTH SUMATERA DERIVED FROM AUDIO MAGNETOTELLURIC DATA}

\author{
Asep Sugianto dan Tony Rahadinata \\ Pusat Sumber Daya Geologi, Jl. Soekarno Hatta No. 444 Bandung \\ Email: asep.soegie@gmail.com
}

SARI

Tahanan jenis batuan merupakan salah satu sifat fisika batuan yang dapat digunakan untuk menganalisis suatu sistem panas bumi. Salah satu metode yang dapat digunakan untuk menentukan nilai tahanan jenis batuan adalah metode audio magnetotellurik (AMT). Metode tersebut telah diaplikasikan di daerah panas bumi Dolok Marawa, Sumatera Utara untuk mendelineasi struktur tahanan jenis bawah permukaan yang berkorelasi dengan sistem panas bumi. Pengukuran AMT dilakukan pada 61 titik ukur yang membentuk 6 lintasan berarah baratdaya-timurlaut dengan jarak antar titik ukur sekitar $500 \mathrm{~m}$ hingga $1000 \mathrm{~m}$. Hasil pemodelan AMT 2D memperlihatkan struktur tahanan jenis bawah permukaan yang membentuk suatu graben di sekitar mata air panas Tinggi Raja. Di bagian atas terdapat kelompok nilai tahanan jenis rendah $<20$ Ohm.m dengan ketebalan sekitar $500 \mathrm{~m}$ yang diinterpretasikan sebagai batuan ubahan (batuan penudung). Di bagian bawahnya terdapat kelompok nilai tahanan jenis lebih tinggi sekitar 30-100 Ohm.m yang diinterpretasikan sebagai zona dengan temperatur tinggi (zona prospek). Secara lateral, zona tersebut dibatasi oleh kontras nilai tahanan jenis rendah dan tinggi di sebelah baratdaya, baratlaut, timurlaut, dan tenggara.

Kata kunci: Tahanan jenis, Audio Magnetotellurik, Dolok Marawa, Sumatera, graben, panas bumi

\begin{abstract}
Resistivity is one of physical properties used for characterizing geothermal system, which can be determined by audio magnetotelluric method (AMT). The method has been conducted at Dolok Marawa to delineate subsurface resisivity structure that correlated with geothermal system. AMT measurement had been conducted at 61 stations within 6 SW-NE lines with spacing about $500 \mathrm{~m}$ to $1000 \mathrm{~m}$. Result of 2D AMT modeling shows resistivity structure form a graben around Tinggi Raja hotsprings. Low resistivity layer $<20$ Ohm.m with $500 \mathrm{~m}$ thickness near surface is interpreted as altered rocks (clay cap). Below this layer is a more resistive layer about 30-100 Ohm.m that is interpreted as high temperature zone (prospect zone). Contrast resistivity value in the southwestern part (AMTD-34), northwestern part (AMTD-20), northeastern part (AMTD-38), and southeastern part (AMTD-50) is a border for the prospect zone laterally.
\end{abstract}

Keywords: Resistivity, Audio Magnetotelluric, Dolok Marawa, Sumatera 


\section{PENDAHULUAN}

Tahanan jenis batuan merupakan salah satu sifat fisika batuan yang sering digunakan dalam menganalisis suatu sistem panas bumi. Suatu sistem panas bumi umumnya tersusun atas batuan penudung berupa batuan alterasi, seperti smectite dan illite yang memiliki nilai tahanan jenis $<10$ Ohm.m dan batuan reservoir yang umumnya berupa propyllitic dengan nilai tahanan jenis $10-60$ Ohm.m (Johnston dkk., 1992). Penentuan nilai tahanan jenis batuan tersebut dapat dilakukan dengan berbagai metode geofisika, diantaranya tahanan jenis DC, polarisasi terimbas (IP), magnetotellurik (MT), audiomagnetotellurik (AMT), dan sebagainya. Dari metode-metode tersebut, metode magnetotellurik merupakan metode geofisika yang sering digunakan dalam survei panas bumi karena memiliki penetrasi yang dalam $>5 \mathrm{~km}$ dan dapat mendeteksi lapisan konduktif diantara lapisan batuan resistif yang tebal (Ushijima, dkk., 2000). Penerapan metode MT dalam eksplorasi panas bumi tersebut telah banyak dibahas dan dipublikasikan, diantaranya oleh Mulyadi dan Guntur (1998), Ushijima dkk. (2005), Uchida (2005), Sugianto, dkk. (2010), dan Sugianto, dkk. (2011).

Pada makalah ini dibahas mengenai penerapan metode audiomagnetotellurik (AMT) untuk mendelineasi struktur tahanan jenis bawah permukaan yang berkorelasi dengan sistem panas bumi. Prinsip kerja metode AMT tersebut sama dengan metode MT, tetapi memiliki penetrasi yang lebih dangkal jika dibandingkan dengan metode MT. Penerapan metode AMT ini dapat digunakan untuk mendelineasi struktur tahanan jenis pada sistem panas bumi yang dangkal.

Metode AMT tersebut diaplikasikan pada daerah panas bumi Dolok Marawa yang terletak di Kecamatan Silau Kahean, Kabupaten Simalungun, Sumatera Utara (Gambar 1). Daerah panas bumi tersebut berada di sebelah timur sesar Sumatera dan sebelah timurlaut Pembangkit Listrik
Tenaga Panas Bumi (PLTP) Sibayak. Penelitian kepanasbumian di daerah ini telah banyak dilakukan, diantaranya oleh Setiawan, dkk. (2006), Suryakusuma, dkk. (2006), Zarkasyi, dkk. (2006), Sundhoro, dkk. (2006), dan Sugianto dan Rahadinata (2015). Hasil penelitian sebelumnya menggambarkan bahwa reservoir panas bumi di daerah ini cukup dangkal $(<1000 \quad \mathrm{~m})$. Penelitian dengan menggunakan metode AMT ini dapat memberikan gambaran mengenai struktur tahanan jenis batuan yang berkorelasi dengan sistem panas bumi di daerah Dolok Marawa. Hasil survei geologi oleh Setiawan, dkk. (2006) menyebutkan bahwa daerah ini umumnya tersusun atas batuan andesit, aliran dan jatuhan piroklastik yang semuanya berumur Kuarter. Di daerah ini juga ditemukan endapan travertin di sekitar mata air panas Tinggi Raja dan batugamping yang menjadi batuan dasar daerah ini di sekitar mata air panas Bahbutala (Gambar 2). Struktur geologi yang berkembang di daerah ini umumnya berarah baratlauttenggara mengikuti pola umum arah sesar Sumatera. Manifestasi panas bumi muncul berupa mata air panas dengan temperatur antara $37^{\circ} \mathrm{C}$ hingga $65^{\circ} \mathrm{C}$ yang tersebar di beberapa tempat.

\section{METODE}

Metode AMT sama halnya dengan metode MT merupakan salah satu metode geofisika yang memanfaatkan gelombang elektromagnetik (medan listrik dan medan magnetik) secara alami (Vozoff, 1991). Prinsip metode AMT sama dengan metode MT, tetapi memiliki rentang frekuensi pengukuran yang berbeda. Metode AMT memiliki rentang frekuensi 0,1-10.000 Hz, sedangkan metode MT memiliki rentang frekuensi $0.0001-1000$ $\mathrm{Hz}$, sehingga penetrasi kedalaman metode AMT lebih dangkal jika dibandingkan dengan penetrasi kedalaman metode MT. Hasil pengukuran AMT umumnya ditampilkan dalam nilai tahanan jenis semu yang merupakan perbandingan besarnya medan listrik dan medan magnet dengan menggunakan asumsi gelombang bidang. 


\section{MAKALAH ILMIAH}

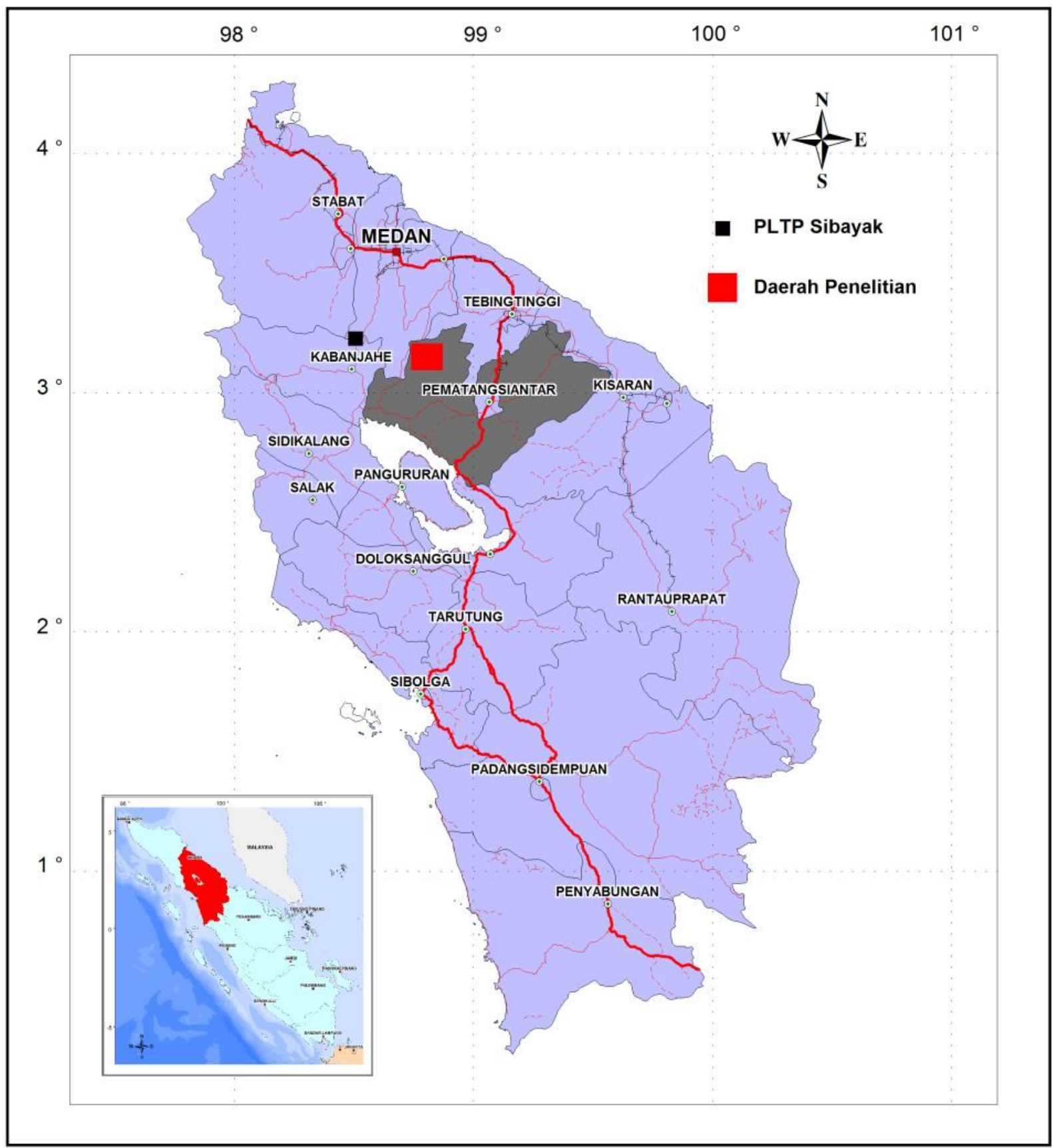

Gambar 1. Peta lokasi daerah panas bumi Dolok Marawa

Secara matematis nilai tahanan jenis semu dapat ditulis sebagai berikut:

$\rho_{a}=\frac{1}{5 f} \times\left|\frac{\mathbf{E}}{\mathbf{H}}\right|^{2}$

dimana, $\rho_{a}$ merupakan tahanan jenis semu (Ohm-m), $f$ adalah frekuensi $(\mathrm{Hz}), \mathbf{E}$ adalah besarnya medan listrik $(\mathrm{mV} / \mathrm{km})$, dan $\mathbf{H}$ adalah besarnya medan magnet (nT). Pengukuran AMT dilakukan terhadap 61 titik ukur pada 6 lintasan berarah baratdaya-timurlaut dengan jarak antar titik ukur sekitar $500 \mathrm{~m}$ hingga 1000 m (Gambar 3). Pemodelan 2D data AMT dilakukan dengan menggunakan algoritma Nonlinear Conjugate Gradient (NLCG) dari Rodi dan Mackie (2001) yang tersedia dalam perangkat lunak WinGlink. Algoritma tersebut digunakan untuk meminimalisasi persamaan solusi inversi dari Tikhonov dan Arsenin (1977), yang dapat dinyatakan dengan persamaan: 


\section{MAKALAH ILMIAH}

$\Psi(\mathrm{m})=(\mathrm{d}-F(\mathrm{~m}))^{\top} \mathbf{V}^{-1}(\mathrm{~d}-\mathrm{F}(\mathrm{m}))+\lambda \mathbf{m}^{\top} \mathbf{L}^{\top} \operatorname{Lm} . .(2)$ dimana d merupakan data pengukuran, $m$ adalah vektor model, $F$ adalah operator pemodelan kedepan, $\mathrm{V}$ adalah matriks error covariance, $\mathrm{L}$ adalah operator linier, dan $\lambda$ adalah parameter regularisasi.

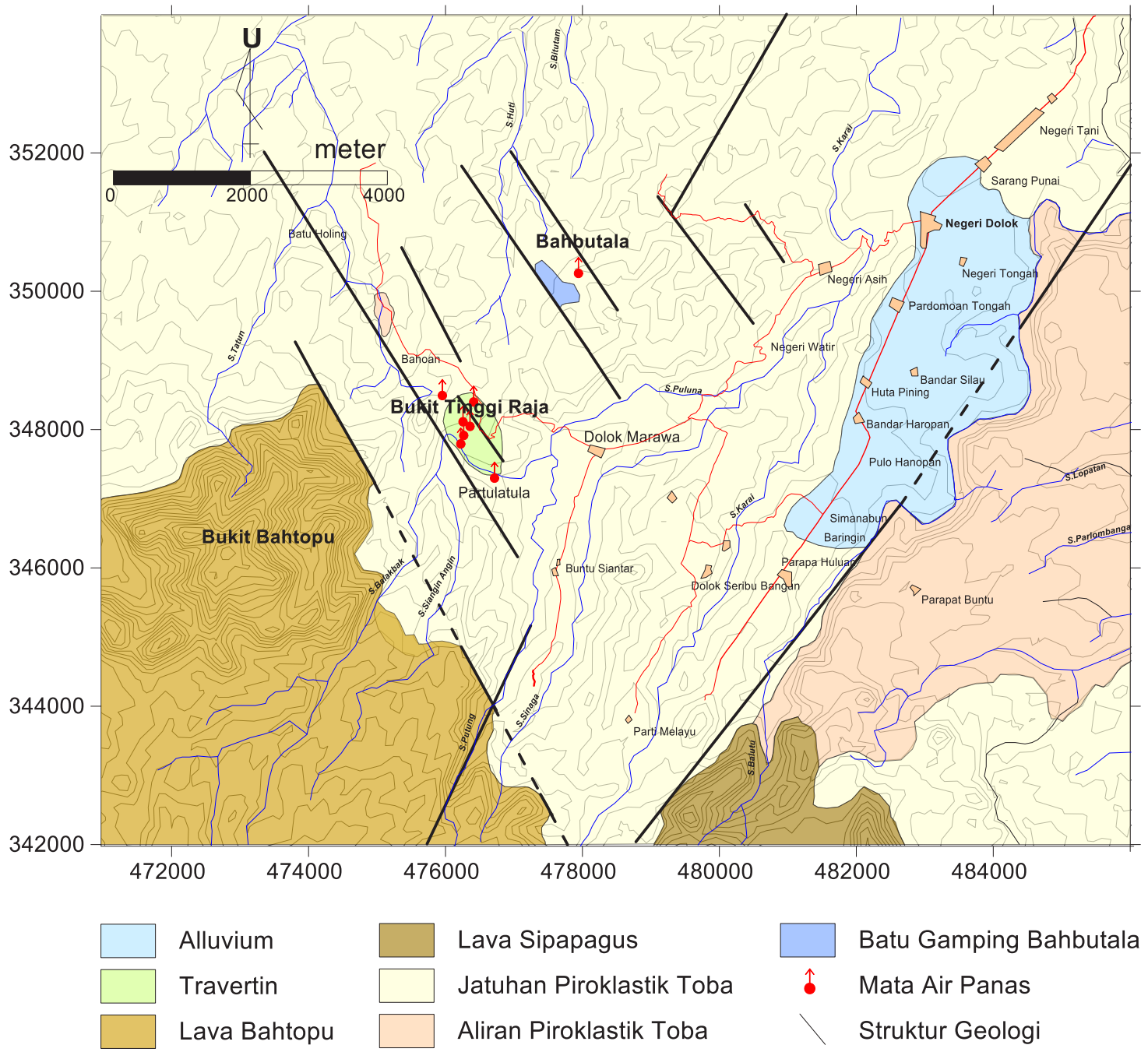

Gambar 2. Peta geologi daerah panas bumi Dolok Marawa

Sistem koordinat peta menggunakan Universal Tranverse Mercator WGS 84 zona $47 \mathrm{~N}$

(modifikasi dari Setiawan dkk., 2006)

\section{HASIL}

Hasil penelitian disajikan dalam bentuk penampang model tahanan jenis $2 \mathrm{D}$ dan peta tahanan jenis pada kedalaman tertentu. Penampang model tahanan jenis 2D terdiri atas 6 lintasan yang berarah baratdaya-timurlaut (Gambar 4).

Penampang model 2D tersebut disajikan untuk menggambarkan distribusi nilai tahanan jenis secara vertikal. Distribusi nilai tahanan jenis secara lateral disajikan dalam bentuk peta tahanan jenis pada kedalaman $100 \mathrm{~m}, 300 \mathrm{~m}, 500 \mathrm{~m}, 750 \mathrm{~m}$, dan 1000 m (Gambar 5).

\section{Model Tahanan Jenis AMT 2D}

Hasil pemodelan 2D lintasan 1 yang berada sebelah baratlaut memberikan $\mathrm{rms}$ error sekitar 5.3\% (Gambar 4). Pola sebaran tahanan jenis dapat dikelompokkan menjadi tiga lapisan. Lapisan pertama memiliki nilai tahanan 


\section{MAKALAH ILMIAH}

jenis $>1000$ Ohm.m yang tersebar di dekat permukaan. Lapisan kedua tersebar memanjang dari baratdaya hingga ke timurlaut dengan nilai tahanan jenis $<20$ Ohm.m. Lapisan kedua tersebut memiliki ketebalan sekitar $500 \mathrm{~m}$. Lapisan ketiga merupakan lapisan resistif dengan nilai tahanan jenis >1000 Ohm.m. Lapisan ketiga ini berada pada kedalaman sekitar $1000 \mathrm{~m}$ dan tersebar dari baratdaya hingga ke timurlaut.

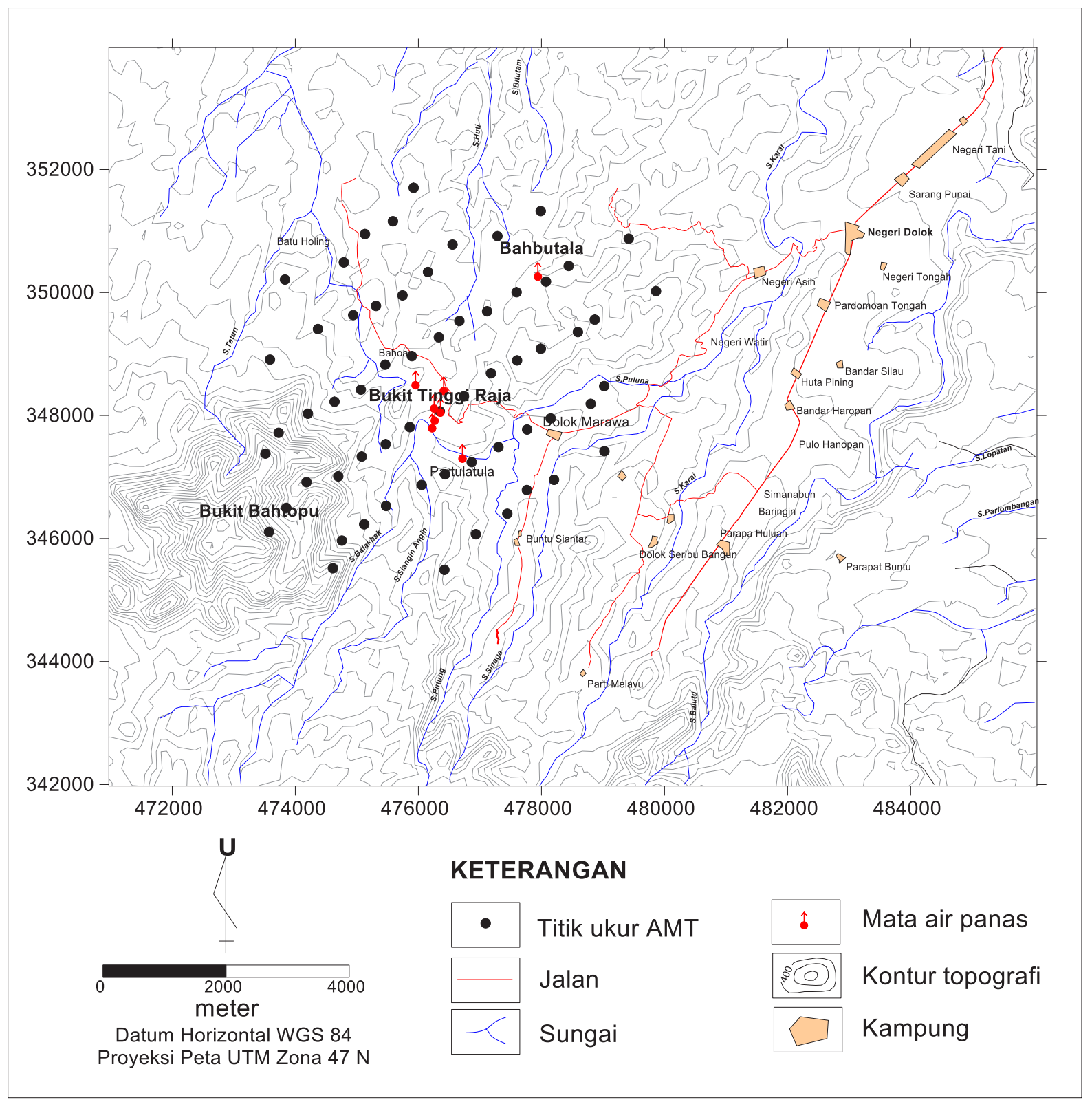

Gambar 3. Sebaran titik ukur AMT daerah panas bumi Dolok Marawa

\section{HASIL}

Hasil penelitian disajikan dalam bentuk penampang model tahanan jenis 2D dan peta tahanan jenis pada kedalaman tertentu. Penampang model tahanan jenis 2D terdiri atas 6 lintasan yang berarah baratdaya-timurlaut (Gambar 4).
Penampang model 2D tersebut disajikan untuk menggambarkan distribusi nilai tahanan jenis secara vertikal. Distribusi nilai tahanan jenis secara lateral disajikan dalam bentuk peta tahanan jenis pada kedalaman $100 \mathrm{~m}, 300 \mathrm{~m}, 500 \mathrm{~m}, 750 \mathrm{~m}$, dan 1000 m (Gambar 5). 


\section{MAKALAH ILMIAH}

\section{Model Tahanan Jenis AMT 2D}

Hasil pemodelan 2D lintasan 1 yang berada sebelah baratlaut memberikan $\mathrm{rms}$ error sekitar 5.3\% (Gambar 4). Pola sebaran tahanan jenis dapat dikelompokkan menjadi tiga lapisan. Lapisan pertama memiliki nilai tahanan jenis $>1000$ Ohm.m yang tersebar di dekat permukaan. Lapisan kedua tersebar memanjang dari baratdaya hingga ke timurlaut dengan nilai tahanan jenis $<20$ Ohm.m. Lapisan kedua tersebut memiliki ketebalan sekitar $500 \mathrm{~m}$. Lapisan ketiga merupakan lapisan resistif dengan nilai tahanan jenis >1000 Ohm.m. Lapisan ketiga ini berada pada kedalaman sekitar $1000 \mathrm{~m}$ dan tersebar dari baratdaya hingga ke timurlaut.

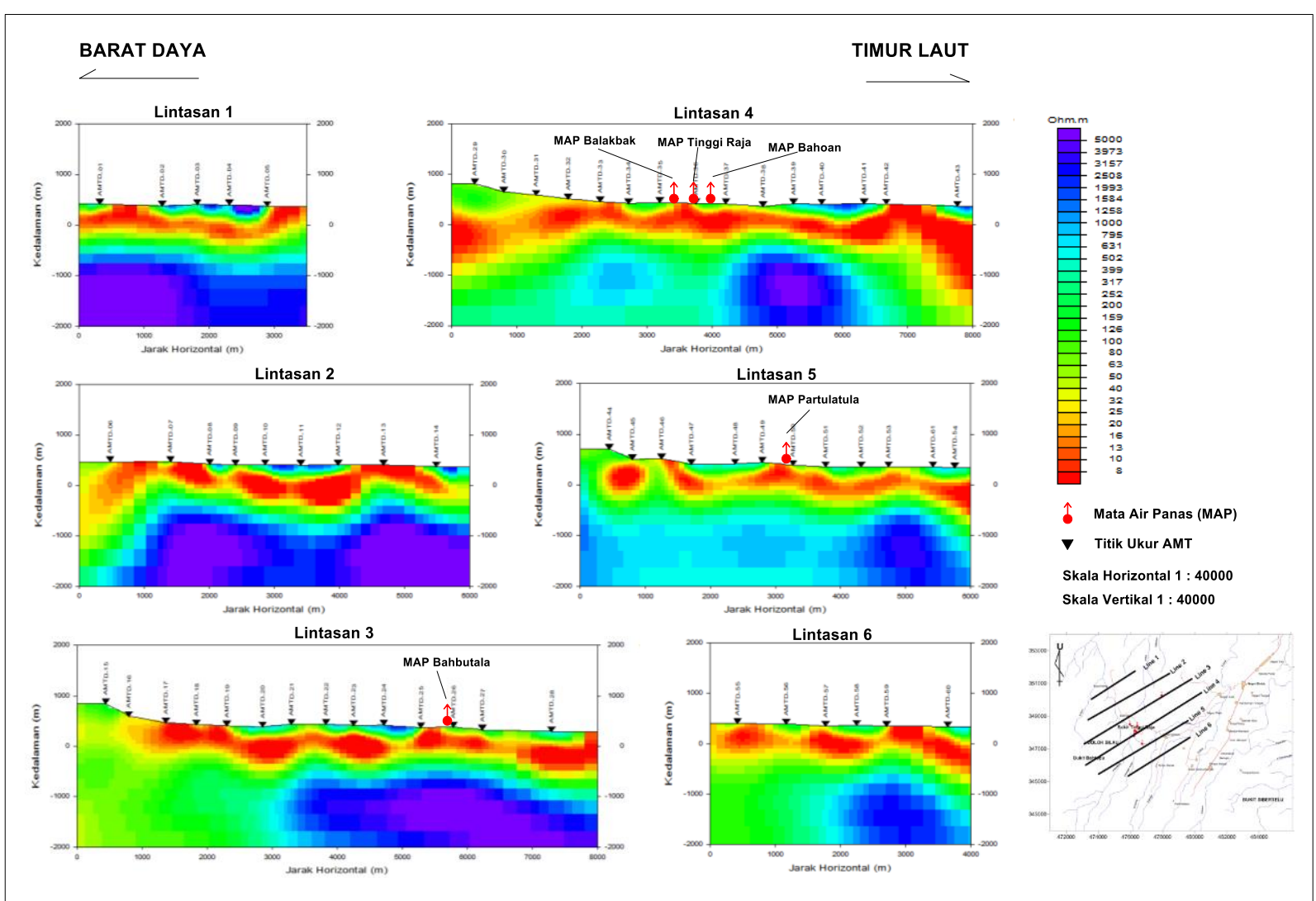

Gambar 4. Model tahanan jenis AMT 2D

Model tahanan jenis AMT 2D pada lintasan 2 memiliki rms error sebesar $6,4 \%$. Hasil pemodelan memperlihatkan tiga kelompok nilai tahanan jenis. Kelompok pertama memiliki nilai tahanan jenis tinggi >1000 Ohm.m dan tersebar tipis di dekat permukaan. Kelompok kedua memiliki nilai tahanan jenis rendah <20 Ohm.m yang tersebar memanjang dari baratdaya hingga ke timurlaut. Lapisan tersebut tersebar di dekat permukaan hingga kedalaman sekitar 1000 meter dengan ketebalan sekitar 500 meter. Kelompok ketiga berada di bagian bawah dan memiliki nilai tahanan jenis sangat tinggi $>1000$ Ohm.m.
Lintasan 3 berada di bagian tengah dan memotong mata air panas Bahbutala. Hasil pemodelan 2D pada lintasan 3 memberikan rms error sebesar $4,5 \%$. Model tahanan jenis 2D tersebut memperlihatkan adanya nilai tahanan jenis tinggi di sekitar titik AMTD-23, AMTD-24, dan AMTD-25 yang tersebar tipis di dekat permukaan. Di bawah nilai tahanan jenis tinggi tersebut, terdapat nilai tahanan jenis rendah <20 Ohm.m yang tersebar memanjang dari sebelah baratdaya hingga ke timurlaut. Di bagian bawah terdapat sebaran nilai tahanan jenis tinggi $>1000$ Ohm.m. Di sekitar titik AMTD-20 terdapat kontras nilai tahanan jenis tinggi dan 
tahanan jenis sedang. Kontras nilai tahanan jenis tersebut bertepatan dengan keberadaan struktur yang berarah baratlaut-tenggara.

Lintasan 4 berada di bagian tengah dan memotong mata air panas Tinggi Raja. Hasil pemodelan tahanan jenis AMT 2D memberikan rms error sebesar 4,5\%. Model tahanan jenis 2D lintasan 4 memperlihatkan sebaran nilai tahanan jenis rendah $<20$ Ohm.m yang memanjang dari baratdaya hingga ke timurlaut. Di bagian bawah terdapat bodi dengan nilai tahanan jenis tinggi >1000 Ohm.m yang berbentuk seperti kubah. Bodi tersebut berada pada kedalaman sekitar $1000 \mathrm{~m}$. Di bagian tengah sekitar titik AMTD-35 dan AMTD-37 terdapat kontras nilai tahanan jenis tinggi dan nilai tahanan jenis sedang yang mengindikasikan adanya struktur.

Hasil pemodelan pada lintasan 5 yang memotong mata air panas Partulatula memiliki $r m s$ error sebesar $4,6 \%$. Pada model tahanan jenis 2D lintasan 5 , nilai tahanan jenis rendah $(<20$ Ohm.m) tersebar dari dekat permukaan hingga kedalaman sekitar $1000 \mathrm{~m}$ dengan ketebalan sekitar $500 \mathrm{~m}$. Di bagian bawah terdapat sebaran nilai tahanan jenis tinggi (>500 Ohm.m) yang memanjang dari baratdaya hingga ke timurlaut. Di sekitar titik AMTD-51 dan AMTD-52 terdapat kontras nilai tahanan jenis $>1000 \mathrm{Ohm} . \mathrm{m}$ dengan nilai tahanan jenis antara 500 Ohm.n s.d. 1000 Ohm. Kontras tersebut mengindikasikan adanya kelurusan sesar.

Hasil pemodelan pada lintasan 6 memiliki rms error sebesar 3,9\%. Seperti pada lintasan 4 dan lintasan 5 , pada lintasan ini nilai tahanan jenis rendah (<20 Ohm.m) juga tersebar di dekat permukaan hingga kedalaman sekitar $1000 \mathrm{~m}$ dengan ketebalan sekitar $500 \mathrm{~m}$. Di bagian bawahnya terdapat nilai tahanan jenis tinggi (>1000 Ohm.m) yang berbentuk seperti kubah. Di bagian tengah sekitar titik AMTD-57 terdapat kontras nilai tahanan jenis tinggi (>1000 Ohm.m) dan nilai tahanan jenis sedang (50 Ohm.m s.d. 300 Ohm.m) yang diperkirakan sebagai indikasi keberadaan struktur sesar di daerah ini.

\section{Peta Tahanan Jenis AMT}

Peta tahanan jenis AMT merupakan sebaran nilai tahanan jenis secara lateral yang disayat dari hasil pemodelan AMT 2D pada kedalaman tertentu. Sebaran nilai tahanan jenis tersebut memiliki pola yang berbeda untuk setiap kedalaman (Gambar 5). Pada kedalaman 100 m, pola sebaran nilai tahanan jenis membentuk kelurusan berarah baratlaut-tenggara di sebelah timurlaut mata air panas Tinggi Raja dan membentuk kelurusan berarah hampir utara-selatan di sekitar mata air panas tersebut. Kontras nilai tahanan jenis rendah dan tinggi mengindikasikan adanya struktur sesar yang secara geologi juga berarah baratlaut-tenggara. Nilai tahanan jenis rendah $(<20$ Ohm.m) tersebar di sebelah barat mata air panas Tinggi Raja dan di sekitar mata air panas Bahbutala. Sebaran nilai tahanan jenis rendah tersebut meluas hampir melingkupi seluruh daerah penelitian pada kedalaman $300 \mathrm{~m}$.

Pada kedalaman $500 \mathrm{~m}$, sebaran nilai tahanan jenis rendah ( $<20$ Ohm.m) masih mendominasi daerah penelitian. Nilai tahanan jenis sedang (50 Ohm.m s.d. 300 Ohm.m) mulai terlihat pada kedalaman $750 \mathrm{~m}$. Perubahan pola dan nilai tahanan jenis mengidikasikan adanya perubahan litologi pada kedalaman tersebut. Pada kedalaman $750 \mathrm{~m}$ terdapat batuan yang lebih resistif jika dibandingkan batuan pada kedalaman $500 \mathrm{~m}$. Nilai tahanan jenis sedang (30 Ohm.m s.d. 500 Ohm.m) dan tinggi (>500 Ohm.m) tersebar luas pada kedalaman $1000 \mathrm{~m}$. Hal ini mengindikasikan bahwa semakin dalam batuan semakin resistif. Pada kedalaman $1000 \mathrm{~m}$ masih terlihat adanya kelurusan berarah baratlaut-tenggara yang mengindikasikan bahwa sesar di daerah ini menerus hingga kedalaman lebih dari $1000 \mathrm{~m}$. 


\section{MAKALAH ILMIAH}

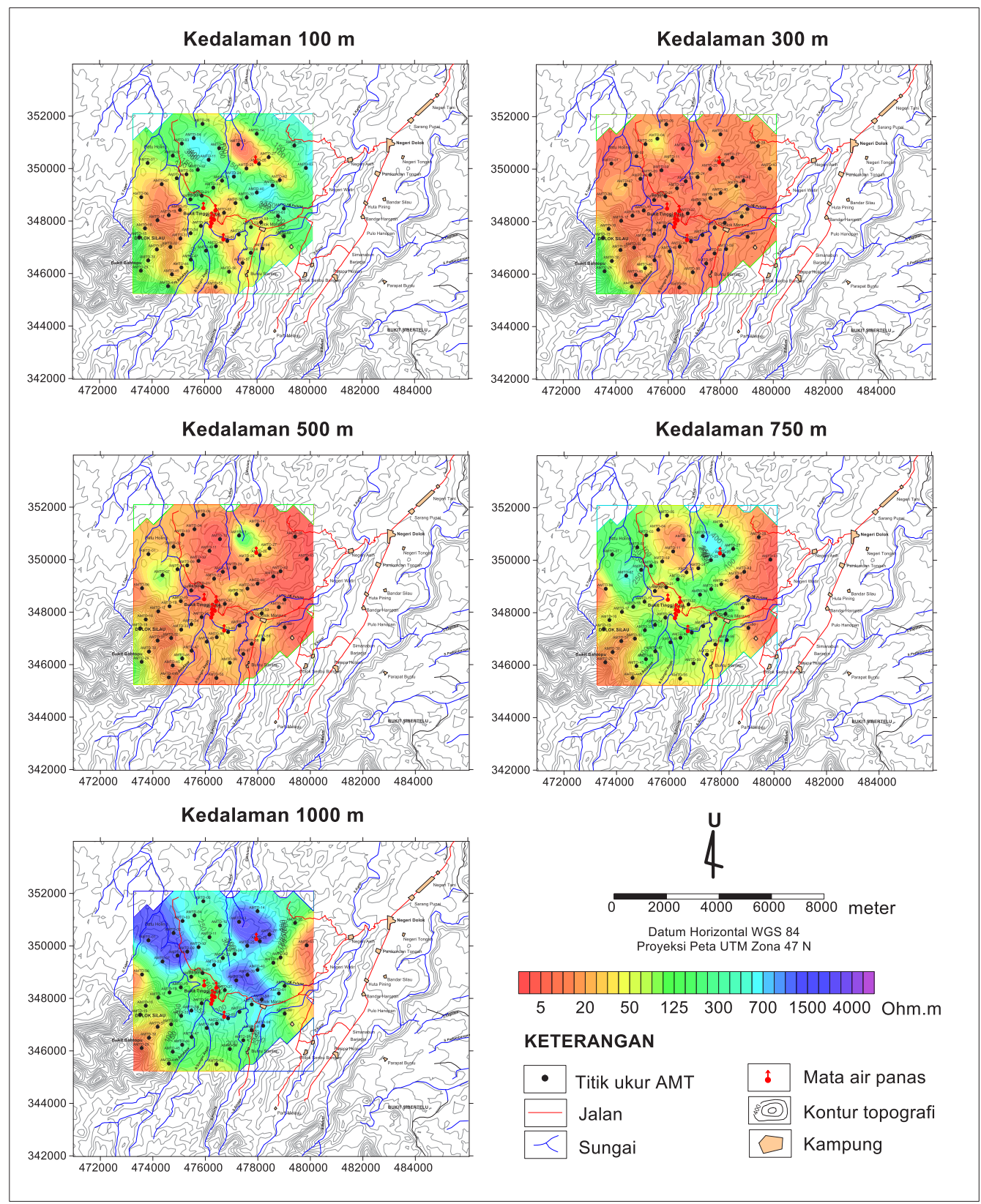

Gambar 5. Peta tahanan jenis AMT pada kedalaman tertentu

\section{PEMBAHASAN}

Hasil pemodelan AMT 2D memperlihatkan struktur tahanan jenis yang secara umum terbagi kedalam 3 kelompok. Kelompok pertama memiliki nilai tahanan jenis tinggi (>500 Ohm.m) dengan ketebalan sekitar $100 \mathrm{~m}$ yang tersebar di sekitar mata air panas Bahbutala. Kelompok kedua memiliki nilai tahanan jenis rendah $(<20$ Ohm.m) yang membentang dari baratdaya hingga ke timurlaut dengan ketebalan bervariasi dari $300 \mathrm{~m}$ sampai $1000 \mathrm{~m}$. Kelompok ketiga berada di bagian bawah dengan nilai tahanan jenis $>500$ Ohm.m yang mengindikasikan batuan bersifat resistif.

Interpretasi terhadap model tahanan jenis AMT 2D lintasan 3 (Gambar 6) memperlihatkan suatu graben yang dibatasi oleh kontras nilai tahanan jenis tinggi (>500 Ohm.m) dan sedang (30 Ohm.m s.d. 500 Ohm.m). Pada model tersebut terlihat adanya sebaran nilai tahanan jenis tinggi (>500 Ohm.m) di sekitar titik AMTD-23, AMTD-24, dan AMTD-25. Nilai tahanan jenis tinggi 
tersebut tersebar dari dekat permukaan hingga kedalaman sekitar $100 \mathrm{~m}$. Secara geologi nilai tahanan jenis tinggi tersebut berasosiasi dengan batugamping Bahbutala yang tersingkap di permukaan. Pada kedalaman sekitar $200 \mathrm{~m}$ hingga $1000 \mathrm{~m}$ tersebar tahanan jenis rendah (<20 Ohm.m) yang memanjang dari baratdaya ke timurlaut dengan ketebalan yang bervariasi antara $300 \mathrm{~m}$ hingga 600 $\mathrm{m}$. Nilai tahanan jenis rendah tersebut diinterpretasikan sebagai respon dari batuan piroklastik jenuh air. Batuan resistif yang dicirikan dengan nilai tahanan jenis tinggi (>500 Ohm.m) terlihat di bagian bawah dan membentang dari tengah hingga ke timurlaut.

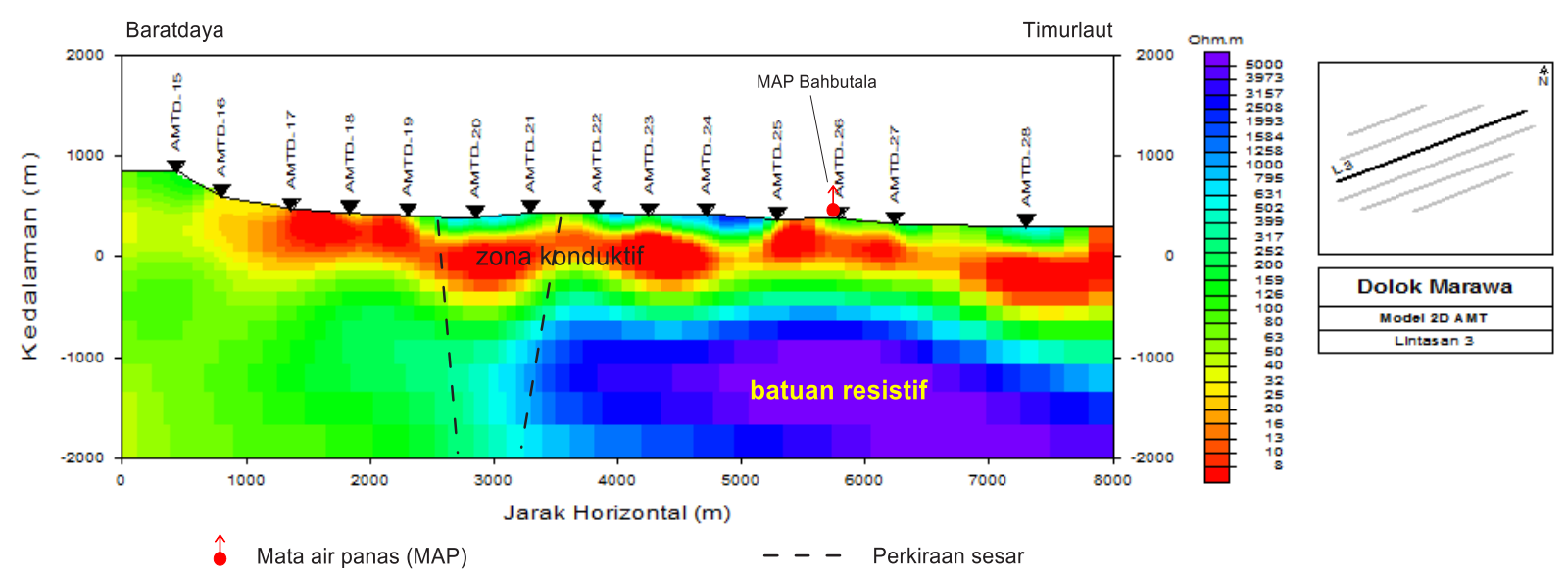

Gambar 6. Interpretasi penampang model lintasan 3

Interpretasi terhadap model tahanan jenis AMT 2D lintasan 4 (Gambar 7) memperlihatkan suatu graben yang ditandai dengan adanya kontras nilai tahanan jenis tinggi (>500 Ohm.m) dan sedang (30 Ohm.m s.d. 500 Ohm.m), seperti pada lintasan 3. Pada model tersebut terdapat nilai tahanan jenis tinggi (>500 Ohm.m) yang tersebar di dekat permukaan dan kedalaman $1000 \mathrm{~m}$. Nilai tahanan jenis tinggi yang berada di dekat permukaan tersebar di sekitar titik AMTD40 dan AMTD-41 dengan ketebalan sekitar $100 \mathrm{~m}$. Nilai tahanan jenis tinggi tersebut diinterpretasikan sebagai bagian dari batugamping Bahbutala yang juga terlihat pada model tahanan jenis AMT 2D lintasan 3. Nilai tahanan jenis tinggi pada kedalaman $1000 \mathrm{~m}$ berbentuk seperti kubah yang mengindikasikan adanya batuan resistif di bagian bawah.

Model tahanan jenis AMT 2D lintasan 4 juga memperlihatkan adanya nilai tahanan jenis rendah $(<20$ Ohm.m) yang tersebar memanjang dari baratdaya hingga ke timurlaut dengan ketebalan bervariasi dari $300 \mathrm{~m}$ sampai dengan $1000 \mathrm{~m}$. Nilai tahanan jenis rendah tersebut diperkirakan berasosiasi dengan batuan piroklastik jenuh air. Batuan piroklastik yang berada pada zona graben diduga telah terubah akibat adanya interaksi dengan fluida panas bumi, sehingga batuan tersebut dapat berperan sebagai batuan penudung pada sistem panas bumi di daerah Dolok Marawa. Di bawah batuan penudung tersebut terdapat nilai tahanan jenis lebih

tinggi (30 Ohm.m s.d. 100 Ohm.m) yang diperkirakan sebagai zona dengan temperatur tinggi (zona prospek). Secara lateral, zona prospek tersebut melebar ke arah baratdaya hingga titik AMTD-34 dan ke arah tenggara hingga AMTD-50 (lihat peta tahanan jenis kedalaman $1000 \mathrm{~m}$, Gambar 5). Zona tersebut dibatasi oleh kontras nilai tahanan jenis tinggi dan rendah di sebelah timurlaut sekitar titik AMTD-38 dan di sebelah baratlaut sekitar titik AMTD-20. 


\section{MAKALAH ILMIAH}

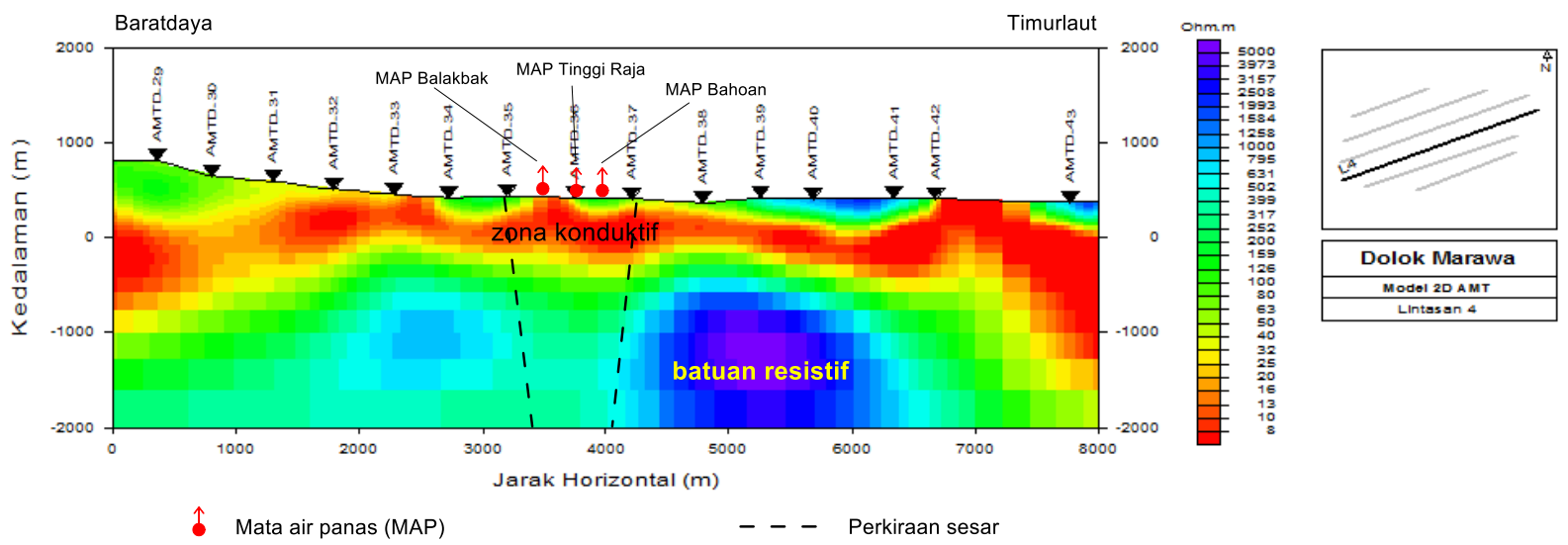

Gambar 7. Interpretasi penampang model lintasan 4

\section{KESIMPULAN}

Metode AMT dapat digunakan untuk menggambarkan struktur tahanan jenis pada suatu sistem panas bumi yang dangkal. Peta tahanan jenis dari hasil pemodelan AMT 2D memperlihatkan sebaran nilai tahanan jenis rendah $(<20$ Ohm.m) yang membentang cukup luas, khususnya pada kedalaman $300 \mathrm{~m}$ dan $500 \mathrm{~m}$. Nilai tahanan jenis rendah tersebut diduga berasosiasi dengan batuan piroklastik jenuh air.

Hasil pemodelan AMT 2D (lintasan 4) memperlihatkan struktur tahanan jenis yang membentuk suatu graben. Keberadaan graben tersebut ditandai dengan kontras nilai tahanan jenis di sekitar mata air panas Tinggi Raja. Nilai tahanan jenis rendah ( $<20$ Ohm.m) yang terletak pada zona graben diduga sebagai batuan piroklastik yang telah terubah akibat adanya interaksi dengan fluida panas bumi. Batuan piroklastik terubah tersebut memiliki ketebalan sekitar $500 \mathrm{~m}$ dan berperan sebagai batuan penudung pada sistem panas bumi Dolok Marawa. Di bawah batuan penudung tersebut terdapat lapisan dengan nilai tahanan jenis lebih tinggi (30 Ohm.m s.d. 100 Ohm.m) yang diperkirakan sebagai zona Mulyadi dan Guntur, B., 1998. Magnteotelluric Method Applied for Exploration of Geothermal Resources in Sumatra. Proceedings Twenty-Third Workshop on Geothermal Reservoir Engineering, Stanford University, California. bertemperatur tinggi (zona prospek). Secara lateral, zona tersebut melebar ke arah baratlaut sekitar titik AMTD-20 dan ke arah tenggara hingga AMTD-50. Zona tersebut dibatasi oleh kontras nilai tahanan jenis rendah dan tinggi di sebelah baratdaya dan timurlaut, yaitu sekitar titik AMTD-34 dan AMTD-38.

\section{UCAPAN TERIMA KASIH}

Penulis menyampaikan apresiasi yang setinggi-tinggi kepada rekan-rekan di Kelompok Penyelidikan Panas Bumi yang telah banyak membantu dan berdiskusi dengan penulis, khususnya anggota tim Survei Gaya Berat dan Audio Magnetotellurik daerah panas bumi Dolok Marawa. Tidak lupa, Penulis juga mengucapkan terima kasih kepada para editor dan mitra bestari yang telah memberikan banyak saran demi kesempurnaan makalah ini.

\section{DAFTAR PUSTAKA}

Johnston, J.M., Pellerin, L., dan Hohmann, G.W., 1992. Evaluation of Electromagnetic Methods for Geothermal Reservoir Detection. Geothermal Resources Council Transactions, 16, h. 241-245.

Rodi, W., Mackie, R.L., 2001. Nonlinear Conjugate Gradients Algoritm for 2$D$ Magnetotellurics Inversion. Geophysics, 66, h. 174-187.

Setiawan, D.I., Setiadarma, D., Sundhoro, H., Sulaeman, B., 2006. Penyelidikan Geologi dan Geokimia 
di Daerah Panas Bumi Dolok Marawa, Kabupaten Simalungun, Sumatera Utara. Proceeding Pemaparan Hasil-Hasil Kegiatan Lapangan dan Non Lapangan Tahun 2006 Pusat Sumber Daya Geologi, Bandung.

Sugianto, A. dan Kristianto, A., 2011. Survei Magnetotellurik Daerah Panas Bumi Kepahiang Kabupaten Kepahiang, Bengkulu. Prosiding Hasil Kegiatan Pusat Sumber Daya Geologi Tahun 2011, Bandung.

Sugianto, A. dan Rahadinata, T., 2015. Pemodelan Gaya Berat Daerah Panas Bumi Dolok Marawa, Kabupaten Simalungun, Sumatera Utara. Buletin Sumber Daya Geologi, Vol. 10, No. 2.

Sugianto, A., Suhanto, E., dan Marpaung, $\mathrm{H}$., 2010. Survei Magnetotellurik Daerah Panas Bumi Gunung ArjunoWelirang, Jawa Timur. Prosiding Hasil Kegiatan Pusat Sumber Daya Geologi Tahun 2010, Bandung.

Sundhoro, H., Bakrun, Suryakusuma, D., Sulaeman, B., Situmorang T., 2006. Survei Panas Bumi Terpadu (Geologi, Geokimia, dan Geofisika) Daerah Dolok Marawa, Kabupaten Simalungun, Sumatera Utara. Proceeding Pemaparan Hasil-Hasil Kegiatan Lapangan dan Non Lapangan Tahun 2006 Pusat Sumber Daya Geologi, Bandung.

Suryakusuma, D., Situmorang D., Sumarna, Sunarto, Hasanudin, 2006. Penyelidikan Gaya Berat dan Geomagnet Daerah Panas Bumi Dolok Marawa Kabupaten Simalungun, Propinsi Sumatera
Utara. Proceeding Pemaparan HasilHasil Kegiatan Lapangan dan Non Lapangan Tahun 2006 Pusat Sumber Daya Geologi, Bandung.

Tikhonov, A. N., and Arsenin, V. Y., 1977. Solutions of ill-posed problems. V. H.Winston and Sons.

Uchida, T., 2005. Three-Dimensional Magnetotelluric Investigation in Geothermal Fields in Japan and Indonesia. Proceedings World Geothermal Congress 2005, Antalya, Turkey.

Ushijima, K., Mustopa, E.J., Jotaki, H., dan Mizunaga, H., 2005. Magnetotelluric Soundings in the Takigami Geothermal Area, Japan. Proceedings World Geothermal Congress 2005, Antalya, Turkey.

Ushijima, K., Tagomori, K., dan Pelton, W.H., 2000. 2D Inversion of VES and MT Data in Geothermal Area. Proceedings World Geothermal Congress 2000, Kyushu-Tohoku, Japan.

Vozoff, K., 1991. The Magnetotelluric Method. Pada: Mabighian, M.N., Electromagnetic Methods in Applied Geophysics, vol. 2. Society of Exploration Geophysicists, Tulsa, OK, h. 641-707.

Zarkasyi, A., Bakrun, Widodo, S., 2006. Penyelidikan Geolistrik Daerah Panas Bumi Dolok Marawa, Kabupaten Simalungun, Provinsi Sumatera Utara. Proceeding Pemaparan Hasil-Hasil Kegiatan Lapangan dan Non Lapangan Tahun 2006 Pusat Sumber Daya Geologi, Bandung.

\begin{tabular}{|ll|}
\hline Diterima & $:$ 25 Agustus 2015 \\
Direvisi & $: 5$ Oktober 2015 \\
Disetujui & $:$ 26 November 2015 \\
\hline
\end{tabular}

